\title{
The Effectiveness of Development Planning of Civil Servants Apparatus in Improving Competence in 2019
}

\author{
Muhammad Isa*1 Rasyidin'² \& M. Akmal² \\ 1Student of the Master Program of Public Administration, Universitas Malikussaleh, Aceh Utara, Indonesia \\ 2Master Program of Public Administration, Universitas Malikussaleh, Aceh Utara, Indonesia \\ *Corresponding Author: isanewin@gmail.com
}

\begin{abstract}
This study examines the effectiveness of the development planning of the state civil apparatus in increasing competence. The research objective is to understand how the planning for the development of the state civil apparatus in increasing competence by the Bener Meriah District Education and Training Personnel Board. The theoretical perspectives used are public administration theory, planning effectiveness theory, state civil servant resource management theory, and competency development. The research method used is qualitative. The results showed that planning for the development of the state civil apparatus in increasing competence by BKPP Bener Meriah Regency is still not effective, this can be seen from the indicators of planning effectiveness according to Cambel JP, including program success, target success, satisfaction with the program, levels of input and output and achievement of goals. all of which are still ineffective. Internal obstacles are due to the lack of budget for the education and training program so that they cannot provide competency development training for ASNs, and external obstacles are due to the lack of interest in ASNs to improve competence due to high training costs and lack of commitment from SKPK leaders in Bener Meriah Regency in motivating ASNs to improve their competence.
\end{abstract}

Keywords: effectiveness; competency development; asn

\section{Introduction}

The development of the competence of the state civil apparatus is generally regulated in Law Number 5 of 2014 concerning State Civil Apparatus and Government Regulation Number 11 of 2017 concerning the Management of Civil Servants. In Government Regulation Number 11 of 2017 concerning Civil Servant Management, Article 203 Paragraph 4 states that competency development for every Civil Servant is carried out for at least 20 (twenty) lesson hours in 1 (one) year. The competence of these Civil Servants can be seen through the recapitulation of the State Civil Service Professionalism Index, which includes the development of the competence of the State Civil Service through various education and training that has been followed. So that competency development becomes the basis for career development and becomes one of the bases for appointment in a position.

Based on data from the Professionalism Index for State Civil Servants in Aceh Province, the percentage shows that the professionalism index for the state civil servants is at moderate qualification with a percentage of $79.85 \%$. This suggests that the planning for the development needs of the state civil apparatus has not been optimal as expected by the law. The competence and performance of the state civil apparatus are still lacking and the local governments pay little attention to competency development through education and training for the state civil apparatus.

Based on the observations of researchers following the demands of the government, the state civil apparatus is obliged to provide good services to the public even obliged to become heavy and smart and competent State Civil Servants, but the opportunity for the State Civil Apparatus in Bener Meriah Regency to develop its competence is following Government Regulation Number 11 of the Year 2017 Regarding the Management of Civil Servants, it is mandatory for all State Civil Servants to develop competencies following effective and efficient development planning, which is still very low.

Based on the index for the development of the competence of the state civil apparatus in 2019 in Bener Meriah Regency, it shows that the very low category of the competence of the state civil apparatus has the highest percentage, namely $66 \%$ compared to the low category $17.7 \%$, moderate $9.5 \%$, high $6.5 \%$, and very 
high $0.3 \%$.

This shows that competency development in Bener Meriah Regency for state civil servants is still ineffective with a high percentage of the competency category of State Civil Servants with a very low type when compared to several neighboring districts/cities of Bener Meriah Regency.

When compared with the data on the competency index of the state civil servants in 2018 and the competency index data for the 2019 state civil servants in Bener Meriah Regency, there was an increase in the percentage of very low competency categories from $64.68 \%$ in 2018 to $66 \%$ in 2019.

Based on the consideration of this phenomenon, researchers are interested in researching the topic of the effectiveness of competency development planning for state civil servants in the Bener Meriah Regency.

\section{Formulation of the problem}

1. How effective is the planning for the development of the state civil apparatus in increasing competence in 2019 at the Bener Meriah District Education and Training Personnel Board ?.

2. What hinders the effectiveness of planning for the development of the state civil apparatus in increasing competence in 2019 at the Bener Meriah District Education and Training Personnel Board ?.

\section{Literature Review}

The theory is a very important foundation in understanding, interpreting, and interpreting data, therefore to facilitate interpreting the data in this study, the authors use several theories as follows:

\section{Public Administration}

According to Chander and Plano in Keban (2004: 3) suggest that: "Public Administration is a process in which public resources and personnel are organized and coordinated to formulate, implement, and manage (manage) decisions in the public."

Meanwhile, Henry in Harbani Pasolong (2008: 8) states that: "Public Administration is a complex combination of theory and practice, with the aim of promoting understanding of the government in relation to the society being governed, and also encouraging public policy to be more responsive. towards social needs. "

Public administration seeks to institutionalize management practices to better match the values of effectiveness, efficiency, and fulfillment of community needs. Meanwhile, Waldo in Pasolong (2008: 8) defines "Public administration is the management and organization of people and their equipment to achieve government goals.

\section{Planning Effectiveness}

According to Cambel J.P (1989: 121), the measurement of effectiveness in general, and the most prominent are:
a. Program success
b. Target success
c. Satisfaction with the program
d. Input and output levels
e. Achievement of overall goals

So that program effectiveness can be carried out with operational capabilities in carrying out work programs in accordance with predetermined goals, comprehensively, effectiveness can be interpreted as the level of the ability of an institution or organization to be able to carry out all its main tasks or to achieve predetermined goals. previous.

\section{Human Resource Management of the State Civil Apparatus}

Management of the State Civil Apparatus is regulated in Law of the Republic of Indonesia Number 5 of 2014 concerning State Civil Servants. In the General Provisions, it is said that ASN Management is the management of ASN to produce ASN employees who are professional, have basic values, professional ethics, free from political intervention, clean from practices of corruption, collusion, and nepotism. Therefore, in realizing the State Civil Apparatus as a bureaucratic reform, it is necessary to establish the State civil apparatus as a profession which has the obligation to manage and develop itself and is obliged to be accountable for its performance and apply the principle of merit in the implementation of the management of the State civil apparatus.

\section{Competency Development of State Civil Apparatus}

The definition of technical competence according to Perka BKN No.8/2013 concerning Guidelines for the Formulation of PNS Technical Competency Standards is the workability of every civil servant which 
includes aspects of knowledge, skills and work attitudes that are absolutely necessary for carrying out their job duties. This working knowledge is the knowledge possessed by ASN in the form of facts, information, expertise obtained by a person through education and experience, both theoretical and practical understanding, and various things that are known by ASN related to their work and the awareness that ASN gets through the experience of a fact or situation in the context. More details related to competency development are described in the Government Regulation of the Republic of Indonesia Number 11 of 2017 concerning Management of State Civil Servants in article 162. Competency development contained in article 162 states that career development, competency development, career patterns, transfers, and promotions are management civil servant careers that must be carried out by applying the principle of the Merit System.

\section{Methods}

This research uses qualitative research with a descriptive analysis approach, because the problem is very comprehensive, in-depth and very broad. Data collection was carried out by observation, interviews and documentation.

\section{Results and Discussion}

The planning for the development of the state civil apparatus in improving competence in 2019 by the Bener Meriah District Education and Training Personnel Board based on the results of observations, interviews and documentation is known to be still ineffective and inefficient. In this study, researchers used Cambel J.P's theory with indicators of effectiveness in the form of program success, target success, satisfaction with the program, levels of input and output, and overall goal achievement to analyze the problems that occurred.

Based on the results of the study, it is known that the program's success indicators have not been effective due to activities and programs that have been planned have not been implemented and the programs so far implemented by the Bener District Education and Training Personnel Agency are still limited to leadership training, training and have not focused on development programs. or increasing the competence of the state civil apparatus, and programs implemented are still constrained by the budget from the Bener Meriah Regency Government.

The next indicator is the success of the target which is still not effective because it is closely related to the success of the program. The results showed that the program planned for the development of ASN competencies was not yet effective so that it affected the success of the targets and targets to be achieved by the Bener Meriah District Education and Training Personnel Agency in developing the competence of its ASNs and so it was difficult to achieve the success of the targets targeted to be able to increase the ranking. competence of state civil servants in the ASN professionalism index

Satisfaction with the program in the effectiveness of ASN competency development planning by the Bener Meriah District Education and Training Personnel Agency is also known to be ineffective, this is due to the Bener Meriah District Education and Training Personnel Board not directly holding competency development training activities but using or facilitating other training institutions. to provide competency development training, thus requiring a financial contribution for ASNs who wish to participate in it, and many ASNs choose not to participate because they are hampered by the costs of such competency development education and training activities.

The next indicator in the effectiveness of ASN competency development planning is the level of input and output which is still ineffective, the researcher has described the scheme of the input and output levels in scheme 4.1, which shows that ASN in Bener Meriah Regency is mostly in the very low competency category, which is $66 \%$ compared to the very high category only $0.3 \%$. So that the level of input and output from the planning for competency development of the state civil servants in Bener Meriah Regency is not balanced and tends to be very low which has an impact on the output obtained by Bener Meriah Regency which is included in the very low category in the ASN professionalism index in Aceh Province.

The last indicator according to Cambel JP to analyze the effectiveness of ASN competency development planning in Bener Meriah Regency is the achievement of overall goals which are still not effective and have not achieved the overall expected goals, objectives and targets, this is due to the success of the program and the success of the targets also not yet effective, so everything is related.

The failure of the overall program, goals, and objectives has not been able to be achieved in accordance with the expectations of the Law and Government Regulation because the Bener Meriah District Education and Training Personnel Board has not prioritized education and training programs for competency development for state civil servants.

This condition reflects that as the achievement of the overall goal of developing the competence of civil servants is the achievement of optimal contribution and services to SKPK, the Bener Meriah Regency Government, and especially to the community so that when the percentage of ASN competencies is very low it reaches a high number, it reflects the service that is very low. not the maximum is given by ASN. 
Barriers to the effectiveness of planning the development of the state civil apparatus in increasing competence in 2019 by the Bener Meriah District Education and Training Personnel Agency for researchers divided into two types, namely internal obstacles, and external obstacles.

Based on the research results, it is known that internal barriers are obstacles that arise from the Bener Meriah District Education and Training Personnel Board, which are related to the lack of budget for educational programs and activities as well as competency development training. So that it cannot provide competency development training for ASNs. Even if it is held by BKPP of Bener Meriah Regency, the number of ASNs that can be included is not much and does not support the increase in competence, especially increasing the ASN professionalism index in Bener Meriah Regency which then due to these internal obstacles makes the planning for developing ASN competencies in Bener Meriah Regency ineffective and efficient to date.

Externally obstacles in planning the development of the state civil apparatus in improving competence in 2019 by the Bener Meriah District Education and Training Personnel Agency are obstacles that arise from outside parties which, among others, are caused by the lack of interest in civil servants participating in competency development training because they are required to pay a fee contribution because the one organizing the training is a private institution facilitated by BKPP Bener Meriah Regency to hold competency development training for ASNs.

\section{Conclusions}

Based on the research results above, it can be concluded as follows:

1. Planning for the development of the state civil apparatus in increasing competence in 2019 in Bener Meriah Regency by the Bener Meriah District Education and Training Personnel Agency is still not effective and efficient, this is shown by indicators of planning effectiveness according to Cambel JP, including program success, target success, satisfaction the program, the level of input and output as well as the achievement of its overall goals which are still not optimal in their implementation. All indicators are closely related to one another, so based on the research results it is known that all indicators show that the effectiveness of ASN competency development planning in Bener Meriah Regency has not been effective.

2. Internal barriers are caused by the lack of budget held by the Bener Meriah District Education and Training Personnel Agency to conduct competency development education and training programs. While external obstacles are due to the lack of interest in ASNs to take part in education and training because it requires them to pay a fairly high contribution fee. Then another external obstacle is the lack of commitment of SKPK leaders in Bener Meriah Regency in encouraging and motivating their staff to want to improve competence to increase the professionalism index ASN Bener Meriah Regency.

\section{Recommendations}

1. It is hoped that the Bener Meriah District Education and Training Personnel Board can evaluate the planning for the development of the state civil apparatus in increasing competence so that in the following years its implementation can be more effective and efficient.

2. It is hoped that ASNs in Bener Meriah Regency will take part in competency development education and training held either through BKPP Bener Meriah Regency or other training institutions because competency development greatly affects the career development of ASNs going forward. It is also hoped that SKPK leaders can participate more actively and commit to motivating staff to develop their competences so that the ASN professionalism index can be increased.

\section{References}

Ali Mufiz. (2004). Pengantar Administrasi Negara. Jakarta: Pusat Penerbitan Universitas Terbuka. Cambel. (1989). Riset dalam Evektivitas Organisasi, Terjemahan Salut Simamora. Jakarta: Erlangga.

Nicholas Henry. (1995). Public Administration and Public Affairs (Sixth Edition), Englewood Cliffs, New Jersey. Peraturan Pemerintah Nomor 11 Tahun 2017 Tentang Manajemen Pegawai Negeri Sipil Peraturan Pemerintah Nomor 17 Tahun 2020 Tentang Manajemen Pegawai Negeri Sipil The Liang Gie. (1979). Unsur-unsur Administrasi. Yogyakarta: Karya Kencana. Thoha, Miftah. (2005). Manajemen Kepegawaian Sipil di Indonesia. Jakarta: Prenada Media Undang-Undang Nomor 5 Tahun 2014 Tentang Aparatur Sipil Negara Utomo Warsito. (2006). Administrasi Publik Baru Indonesia: perubahan padadigma dari administrasi Negara ke administrasi public. Pustaka Pelajar. Yogyakarta. 